\title{
Bovine mastitis bacteria resolved by MALDI-TOF mass spectrometry
}

\author{
Bettina Nonnemann, ${ }^{1 *}$ Ulrike Lyhs, ${ }^{2}$ Line Svennesen, ${ }^{3}$ Katja Ann Kristensen, ${ }^{1}$ Ilka C. Klaas, ${ }^{4}$ \\ and Karl Pedersen ${ }^{1} \dagger$ \\ ${ }^{1}$ National Veterinary Institute, Technical University of Denmark, 2800 Kongens Lyngby, Denmark \\ ${ }^{2}$ Institute for Molecular Medicine Finland, University of Helsinki, Finland, FI-00014 \\ ${ }^{3}$ Section for Production, Nutrition and Health, University of Copenhagen, 1870 Frederiksberg C, Denmark \\ ${ }^{4}$ DeLaval International AB, 14721 Tumba, Sweden
}

\section{ABSTRACT}

Matrix-assisted laser desorption/ionization timeof-flight mass spectrometry (MALDI-TOF MS) is a fast and reliable method to identify the most common pathogenic bacteria in humans and animals. The goals of this study were to amend a commercial database with additional species, evaluate the amended database for identification of bacterial genera and species causing bovine mastitis, and describe the plethora of species involved. In total, 500 udder pathogenic isolates were subjected to MALDI-TOF MS using bacterial or fungal colony material; $93.5 \%$ could be identified to the species level, and $6.5 \%$ were identified only to the genus level. Isolates identified to the genus level required further identification to the species level by conventional methods or $16 \mathrm{~S}$ rDNA sequencing. Mass spectra from verified species were used to expand the MALDI-TOF MS database to improve future identification ability. A total of 24 genera and 61 species were identified in this study. Identified isolates were mainly staphylococci, streptococci, Enterobacteriaceae, and coryneforme bacteria. In conclusion, MALDI-TOF MS is a powerful, rapid, and reliable technique to identify the most common microorganisms causing bovine mastitis, and the database can be continuously expanded and improved with additional species.

Key words: bovine mastitis, matrix-assisted laser desorption/ionization time-of-flight (MALDI-TOF) mass spectrometry, rapid identification

\section{INTRODUCTION}

Bovine mastitis is the most important infection in dairy cows and is an increasing problem partly due

Received August 8, 2018.

Accepted November 16, 2018

*Corresponding author: benon@dtu.dk

$\dagger$ Present address: National Veterinary Institute 751 89, Uppsala, Sweden. to selection for higher milk yield and use of broadspectrum antibiotics (Valde, 2004; Hand et al., 2012; DANMAP, 2014, 2017). Bovine mastitis reduces animal health and welfare and causes severe economic losses to the dairy industry. It is defined by an increased neutrophil concentration in the glandular tissue of the udder, manifested either as abnormal-looking milk secretions, such as discoloration or clots (clinical mastitis; CM) or as an increase in SCC with normal appearance of the milk (subclinical mastitis, SCM) (Barkema et al., 1998; Vanderhaeghen et al., 2010). Bacteria causing mastitis are traditionally divided into 3 main groups: contagious, opportunistic, and environmental bacteria. The most common contagious bacteria are Staphylococcus aureus and Streptococcus agalactiae (Gianneechini et al., 2002) and, less frequently, Mycoplasma bovis. The opportunistic teat skin bacteria include the non-aureus (usually coagulase-negative) staphylococci, which are considered minor pathogens but are emerging as a major concern (Gianneechini et al., 2002; Tenhagen et al., 2006; Mahmmod et al., 2018). Among the environmental pathogens, Escherichia coli, Klebsiella spp., streptococci, and Trueperella pyogenes are often found (Todhunter et al., 1991; Gianneechini et al., 2002; Bi et al., 2016) along with a large number of less frequently occurring species, such as Enterococcus spp., Bacillus spp., Lactococcus spp. Corynebacterium spp., Pasteurella multocida, Pseudomonas spp., and various Enterobacteriaceae, some of which can be difficult to identify correctly using conventional methods (Tenhagen et al., 2006; Botrel et al., 2010). The environmental streptococci are considered a major cause of bovine mastitis. From a veterinary perspective, the sooner the correct antibiotic treatment for a bovine mastitis infection is initiated, the better the prognosis for the cow (Leitner, 2012). In Denmark during the past decade, the use of third- and fourth-generation cephalosporins has decreased significantly for intramammary treatment, whereas use of aminoglycoside-benzyl penicillin combinations has increased. The usage of first-generation cephalosporins has not changed significantly, whereas the use of penicillin has been increasing (DANMAP, 
2017). To ensure rapid initiation of correct treatment and prudent use of antimicrobials, timely and accurate identification of the causative agent of bovine mastitis is crucial.

Identification and isolation of microbes have traditionally relied on biochemical and physiological tests that are laborious and time consuming; for example, bacterial culture, enzymatic tests, and presence of metabolic pathways, such as sugar fermentation or amino acid decarboxylation. However, experience in the hospital system has shown mass spectrometry to be an applicable method in clinical contexts for identification of bacterial isolates cultured on agar or directly from positive blood cultures (Seng et al., 2009; Benagli et al., 2011; Nonnemann et al., 2013). Matrix-assisted laser desorption/ionization time-of-flight mass spectrometry (MALDI-TOF MS) has been introduced as a powerful new tool in the clinical diagnostic laboratory for identification of bacterial and some fungal microbes causing infections. This technique represents a cost-effective alternative to classical phenotypic and biochemical assays and has been used for nearly a decade in routine clinical microbiology laboratories (Eigner, 2009; Seng et al., 2009; Bizzini et al., 2010; Cherkaoui et al., 2010; van Veen et al., 2010; Bader et al., 2011). As few as $5 \times 10^{3} \mathrm{cfu}$ per sample are sufficient to attain species identification by the MALDI-TOF technique (Hsieh et al., 2008). The challenge in using this technique is the extent and accuracy of the reference databases and whether isolates can be matched to reference spectra in a database. Such databases have been evolving and refined over the last few years but with an emphasis on human pathogens. Each isolate is compared with the 10 closest reference spectra in the database in the mass range $(2-20 \mathrm{kDa})$, representing predominantly ribosomal proteins obtained from whole bacteria cells or crude bacterial extracts (Suh et al., 2005). Each species has a variable number of reference entries, from 1 to 14 , depending on how a large variation is known for the specific species. The diversity of the spectra can vary within a species depending on the origin of the bacteria, as demonstrated by Mahmmod et al. (2018). The Biotyper 3.1 software (Bruker Daltonics, Bremen, Germany) provides a log score with a cut-off log score of 2.0 for identification at species level and a score of 1.7 for identification at the genus level. The MALDITOF technique is also gaining ground for bacteria of veterinary importance, originating from bovine, ovine, porcine, and avian sources and, to a lesser extent, of canine, caprine, and equine provenance (Randall et al., 2015). Several researchers have applied the technique to bacterial groups causing bovine mastitis, such as group B streptococci (Barreiro et al., 2010), group D streptococci (Werner et al., 2012), non-aureus staphylococci
(Barreiro et al., 2010; Cameron et al., 2017; Mahmmod et al., 2018), Enterobacteriaceae (Rodrigues et al., 2017; Savage et al., 2017), and even lactational mastitis in humans (Marín et al., 2017). Classical phenotypical and biochemical tests have limitations - they typically take from one to several days to perform and read, and misidentification of bacteria is not uncommon (Bes et al., 2000; Taponen et al., 2006). The consequence is erroneous diagnoses, which may lead to incorrect treatment of bovine mastitis and additional consumption of antibiotics. For almost a decade, the MALDI-TOF MS technique has shown the potential as a fast and reliable bacterial identification method in the hospital sector, although this assay has yet to be implemented in the veterinary sector for bovine mastitis in most laboratories as a routine test.

The goals of this study were to amend a commercial database with additional species, evaluate the amended database for identification of bacterial genera and species causing bovine mastitis, and to describe the plethora of species involved.

\section{MATERIALS AND METHODS}

\section{Bacterial Cultures and Culture Conditions}

A total of 530 bacterial cultures were examined, of which 30 were reference strains from a national mastitis proficiency test (Table 1). Four hundred thirteen cultures were isolates from CM or SCM cases submitted by veterinary practitioners for laboratory investigation either as mastitis secretions (in milk samples) or pure cultures on nutrient agar plates (Table 2). These samples were collected as a diagnostic service for practicing veterinarians as part of a validation of MALDI-TOF for identification of mastitis bacteria. Eighty-seven cultures were subclinical bovine mastitis samples (SCC $>200,000$ cells $/ \mathrm{mL}$ at the DHI test before sampling) collected in a research project on Staph. aureus and Strep. agalactiae mastitis.

Upon arrival at the laboratory, all microorganisms received on primary agar plates were subcultured on Columbia blood agar (Oxoid A/S, Roskilde, Denmark) supplemented with $5 \%$ calf blood, and mastitis secretions were inoculated onto blood agar. All plates were incubated aerobically for 18 to $20 \mathrm{~h}$ at $37^{\circ} \mathrm{C}$ and acquisition for mass spectra for identification was performed.

\section{Isolates for the Technical University of Denmark, National Veterinary Institutes Main Spectrum Database}

Single colonies from sequence-verified stains searched using the BLAST tool of the GenBank Database (https: 
//blast.ncbi.nlm.gih.gov), as described by Strube et al. (2018), were subcultured onto blood agar and incubated overnight aerobically at $37^{\circ} \mathrm{C}$. All isolates for the Technical University of Denmark, National Veterinary Institutes Main Spectrum Database (DTU-Vet MSP Database) in this study were stored at $-80^{\circ} \mathrm{C}$ in Luria Bertani broth with $15 \%$ glycerol.

\section{S rDNA Sequencing}

Isolates that did not meet the criteria for proper species identification by MALDI-TOF MS, log score 2.0, were subjected to further identification by $16 \mathrm{~S}$ rDNA sequencing before inclusion in the local DTU-Vet MSP database of potential animal pathogens as reference spectra (Table 1). The method used was essentially as described by Mahmmod et al. (2018), with modifications. Bacterial colony material was suspended in $1 \mathrm{~mL}$ of PBS and centrifuged for $5 \mathrm{~min}$ at $10,000 \times \mathrm{g}$. The supernatant was removed and the pellet resuspended in $100 \mu \mathrm{L}$ of water. The sample was boiled for $10 \mathrm{~min}$ and immediately placed on ice. The lysate was centrifuged for $30 \mathrm{~s}$ at $10,000 \times g$. The $16 \mathrm{~S} \mathrm{rDNA}$ gene was amplified by PCR in 3 separate products with following primer sets: 10Fx-1509R (5'-AGAGTTTGATCMTGGCTC-3' and $5{ }^{\prime}$-GTTACCTTGTTACGACTTCAC-3'), 10Fx804Rx (5'-AGAGTTTGATCMTGGCTC-3' and 5'-GACTACCNGGGTATCTAATCC-3') and 519Fx1509R (5'-CCAGCAGCCGCGGTAATA-3' and 5'-GTTACCTTGTTACGACTTCAC-3'), where $\mathrm{M}=\mathrm{A}$ or $\mathrm{C}$; and $\mathrm{N}=\mathrm{A}, \mathrm{T}, \mathrm{C}$, or $\mathrm{G}$. The amplification program was run as follows: denaturation at $94^{\circ} \mathrm{C}$ for $6 \mathrm{~min}$, 35 cycles of $94^{\circ} \mathrm{C}$ for $60 \mathrm{~s}, 56^{\circ} \mathrm{C}$ for $60 \mathrm{~s}$, and $72^{\circ} \mathrm{C}$ for $90 \mathrm{~s}$, and final extension $72^{\circ} \mathrm{C}$ for $10 \mathrm{~min}$ in a reaction volume of $50 \mu \mathrm{L}$. Amplified PCR products of expected lengths of 1,499, 990, and $794 \mathrm{bp}$, respectively, were verified by E-Gel (Invitrogen, Carlsbad, CA). Forty microliters of PCR product was purified with MinElute PCR purification kit (Qiagen, Copenhagen, Denmark) and eluted in 10 to $20 \mu \mathrm{L}$ of elution buffer. The amplified 16S rDNA gene was sequenced on an ABI 3130 Genetic analyzer using BigDye Terminator v3.1 Cycle Sequencing Kit (Applied Biosystem, Foster City, CA) according to the manufacturer's protocol, and then the resulting sequences were compared with the described sequences by BLAST search against the GenBank

Table 1. Test of known microorganisms causing bovine mastitis

\begin{tabular}{|c|c|c|c|}
\hline $\begin{array}{l}\text { Characterized isolate } \\
(\mathrm{n}=30)\end{array}$ & No. & $\begin{array}{l}\text { MALDI-TOF MS } \\
\text { identification }\end{array}$ & Score $^{1}$ \\
\hline Bacillus $^{2}$ & 1 & Bacillus licheniformis & $\geq 2$ \\
\hline Enterococcus faecalis & 1 & Enterococcus faecium & $\geq 2$ \\
\hline Enterococcus faecium & 1 & Enterococcus faecalis & $>2$ \\
\hline Escherichia coli & 2 & Escherichia coli & $\geq 2$ \\
\hline Klebsiella pneumoniae & 2 & Klebsiella pneumonia & $\overline{\geq} 2$ \\
\hline Micrococcus ${ }^{3}$ & 1 & Micrococcus luteus & $\overline{\text { No ID }}$ \\
\hline Staphylococcus aureus & 2 & Staphylococcus aureus & $\geq 2$ \\
\hline CNS & 2 & Staphylococcus epidermidis & $\geq 2$ \\
\hline Streptococcus agalactiae & 2 & Streptococcus agalactiae & $\geq 2$ \\
\hline Streptococcus bovis & 1 & Streptococcus lutetiensis ${ }^{4}$ & $>2$ \\
\hline Streptococcus canis $^{3}$ & 1 & Streptococcus canis & $<2$ \\
\hline Streptococcus canis & 1 & Streptococcus canis & $>2$ \\
\hline Streptococcus dysgalactiae & 2 & Streptococcus dysgalactiae & $\geq 2$ \\
\hline Streptococcus uberis & 1 & Streptococcus uberis & $\geq 2$ \\
\hline Streptococcus uberis $^{3}$ & 1 & Streptococcus uberis & $\overline{<} 2$ \\
\hline Trueperella pyogenes & 2 & Trueperella pyogenes & $\geq 2$ \\
\hline Yeast $^{5}$ & 1 & Candida kefyr & $\geq 2$ \\
\hline Yeast $^{5}$ & 1 & Candida krusei & $\geq 2$ \\
\hline Staphylococcus hyicus & 1 & Staphylococcus hyicus & $>2$ \\
\hline Staphylococcus chromogenes & 2 & Staphylococcus chromogenes & $\overline{\geq 2}$ \\
\hline Staphylococcus spp. & 1 & Staphylococcus xylosus & $>2$ \\
\hline Pasteurella multocida & 1 & Pasteurella multocida & $\geq 2$ \\
\hline
\end{tabular}

${ }^{1} \mathrm{~A} \log$ score between 0 and 3 is calculated by the Biotyper algorithm (Bruker Daltonics, Bremen, Germany). $\log$ scores $<1.7$ provide no identification. $\log$ score $1.7>\mathrm{x}<2.0$ indicates genus identification, and $\log$ score $\geq 2$ indicates species identification. All identifications $\geq 2.0$ expressed specific species identification. Next closest score always specified the same species if the score was $\geq 2.0$.

${ }^{2}$ Isolate was exposed to the extraction procedure due to rapid spore formation.

${ }^{3}$ Isolates were identified by API (Biomérieux, Ballerup, Denmark) or sequenced for 16S RNA before being submitted as local spectra to the database.

${ }^{4}$ Streptococcus lutetiensis was not proposed as a species until 2002; prior to 2002, it would have been classified as Streptococcus bovis.

${ }^{5}$ All yeasts were exposed to the extraction procedure. 
Table 2. Bacterial isolates from clinical or subclinical bovine mastitis identified by MALDI-TOF MS

\begin{tabular}{|c|c|c|}
\hline Bacteria & No. & Comment \\
\hline \multicolumn{3}{|l|}{ Gram-positive } \\
\hline Aerococcus viridians & 5 & \\
\hline Bacillus cereus ${ }^{1,2}$ & 1 & \\
\hline Bacillus licheniformis ${ }^{2}$ & 6 & \\
\hline Bacillus pumilus $^{2}$ & 1 & \\
\hline Bacillus safensis ${ }^{2}$ & 1 & \\
\hline Bacillus sphaericus $^{2}$ & 1 & \multirow{4}{*}{ Identified only to genus level } \\
\hline Bacillus spp. $^{2}$ & 2 & \\
\hline Corynebacterium bovis & 4 & \\
\hline Corynebacterium glutamicum & 2 & \\
\hline Corynebacterium spp. & 2 & \multirow[t]{4}{*}{ Identified only to genus level } \\
\hline Corynebacterium xerosis & 1 & \\
\hline Enterococcus faecalis & 5 & \\
\hline Enterococcus hirae & 1 & \\
\hline Helococcus ovis & 1 & \multirow{8}{*}{$\begin{array}{l}\text { Identified only to genus level } \\
\text { Identified only to genus level }\end{array}$} \\
\hline Kocuria carniphila & 1 & \\
\hline Lactococcus garvieae & 5 & \\
\hline Lactococcus lactis & 2 & \\
\hline Lycinibacillus fusiformis & 1 & \\
\hline Lycinibacillus sphaericus & 1 & \\
\hline Micrococcus luteus & 1 & \\
\hline Staphylococcus arlettae & 1 & \\
\hline Staphylococcus aureus & 79 & \multirow[t]{6}{*}{3 small variant colonies, 1 isolate only identified to genus level } \\
\hline Staphylococcus chromogenes & 17 & \\
\hline Staphylococcus cohnii & 1 & \\
\hline Staphylococcus epidermidis & 15 & \\
\hline Staphylococcus equorum & 4 & \\
\hline Staphylococcus haemolyticus & 2 & \\
\hline Staphylococcus hyicus & 3 & \multirow{6}{*}{1 isolate only identified to genus level } \\
\hline Staphylococcus saprophyticus & 3 & \\
\hline Staphylococcus sciuri & 4 & \\
\hline Staphylococcus simulans & 3 & \\
\hline Staphylococcus succinus & 3 & \\
\hline Staphylococcus xylosus & 7 & \\
\hline Staphylococcus warneri & 2 & \multirow[t]{8}{*}{1 isolate only identified to genus level } \\
\hline Streptococcus agalactiae & 15 & \\
\hline Streptococcus dysgalactiae & 31 & \\
\hline Streptococcus parauberis & 1 & \\
\hline Streptococcus uberis & 50 & \\
\hline Streptococcus lutetiensis & 1 & \\
\hline Trueperella pyogenes & 8 & \\
\hline Total gram-positive & 294 & \\
\hline \multicolumn{3}{|l|}{ Gram-negative } \\
\hline Acinetobacter haemolyticus ${ }^{2}$ & 1 & \multirow{13}{*}{ Identified only to genus level } \\
\hline Acinetobacter johnsonii ${ }^{2}$ & 1 & \\
\hline Acinetobacter spp. $^{2}$ & 4 & \\
\hline Aeromonas hydrophila & 1 & \\
\hline Citrobacter braakii & 1 & \\
\hline Citrobacter freundii & 1 & \\
\hline Citrobacter koseri & 1 & \\
\hline Escherichia coli & 64 & \\
\hline Enterobacter cloacae & 4 & \\
\hline Klebsiella pneumoniae & 12 & \\
\hline Klebsiella oxytoca & 2 & \\
\hline Morganella morganii & 2 & \\
\hline Pantoea agglomerans & 2 & \\
\hline Pantoea spp. & 1 & \multirow{10}{*}{ Identified only to genus level } \\
\hline Pasteurella multocida & 3 & \\
\hline Proteus mirabilis & 2 & \\
\hline Proteus penneri & 2 & \\
\hline Proteus vulgaris & 2 & \\
\hline Pseudomonas aeruginosa & 3 & \\
\hline Pseudomonas libanensis & 1 & \\
\hline Pseudomonas putida & 1 & \\
\hline Pseudomonas proteolytica & 1 & \\
\hline Pseudomonas rhodesiae & 1 & \\
\hline
\end{tabular}


Table 2 (Continued). Bacterial isolates from clinical or subclinical bovine mastitis identified by MALDI-TOF MS

\begin{tabular}{lrl}
\hline Bacteria & No. & Comment \\
\hline Pseudomonas spp. & 1 & Identified only to genus level \\
Pseudomonas taetrolens & 1 & \\
Raoultella ornithinolytica & 1 & \\
Serratia liquefaciens & 2 & \\
Serratia marcescens & 1 & \\
Total gram-negative & 119 & \\
\hline
\end{tabular}

${ }^{1}$ Bacillus cereus cannot be distinguished from Bacillus anthracis by MALDI-TOF MS.

${ }^{2}$ Bacillus spp. and Acinetobacter spp. were all submitted to the ethanol:formic acid protocol by default.

database (http://www.ncbi.nlm.nih.gov) as previously described (Strube et al., 2018).

\section{MALDI-TOF}

Species or genus identification was performed by using the Biotyper 3.1 software combined with the DTUVet MSP database (Supplemental Table S1; https:// doi.org/10.3168/jds.2018-15424). Mass spectra were obtained using an Autoflex Speed instrument (Bruker Daltonics, Billerica, MA) calibrated with the Escherichia coli DH5 $\alpha$ Bacterial Test Standard (BTS). The majority $(\mathrm{n}=473)$ of the mastitis isolates were identified by application of a thin smear from pure cultures onto a target plate, covered by $\alpha$-cyano- 4 -hydroxycinnamic acid (HCCA) and submitted to MALDI-TOF MS identification. The remaining samples $(\mathrm{n}=27)$ were extracted, following the ethanol:formic acid:acetonitrile protocol, into crude bacterial extracts, as described by Bizzini et al. (2010). One microliter of crude bacterial extract was applied in triplicate onto the MALDI target plate, air-dried at room temperature $\left(\mathbf{R T} ; 20-22^{\circ} \mathbf{C}\right)$, and covered by HCCA matrix before acquisition was performed.

\section{Database Upgrade}

Single pure colonies $(\mathrm{n}=2-5)$ were transferred to individual 1.5-mL Eppendorf Safe-Lock Tubes (SigmaAldrich, Brøndbyvester, Denmark) containing $300 \mu \mathrm{L}$ of water, ultra-HPLC grade (Merck, Hellerup, Denmark), using sterile 1.0- $\mu \mathrm{L}$ disposable plastic inoculating loops. Tubes were vortexed briefly to create a homogeneous suspension followed by addition of $900 \mu \mathrm{L}$ of $100 \%$ ethanol, liquid chromatography solvent grade grade (Merck) and an additional $15 \mathrm{~s}$ of vortex mixing. Tubes were centrifuged for $3 \mathrm{~min}$ at $12,200 \times g$ at RT, supernatants were poured and discarded, and tubes centrifuged again for $3 \mathrm{~min}$ at $12,200 \times g$ at RT. The remaining ethanol/water was carefully aspirated using a micropipette. Cell pellets were air-dried for $3 \mathrm{~min}$ before the addition of an appropriate volume (15-50 $\mu \mathrm{L}$ ) of $70 \%$ formic acid. The optimal volume of formic acid was determined by visually sizing the pellet. After up to $3 \mathrm{~min}$, an equal volume of $100 \%$ acetonitrile was added to each sample and mixed carefully. Samples were centrifuged for $3 \mathrm{~min}$ at 12,200 $\times \mathrm{g}$ at RT. Eight $1-\mu \mathrm{L}$ volumes of supernatant were carefully placed on a ground steel target plate and allowed to air dry before each spot was overlaid with $1.0 \mu \mathrm{L}$ of $\mathrm{HCCA}$ matrix (Bruker Daltonics) dissolved in 50\% acetonitrile with $2.5 \%$ trifluoroacetic acid (Sigma-Aldrich) (Nonnemann et al., 2013; Cameron et al., 2017).

\section{Evaluation of Bruker Daltonics Database and Improvement of DTU-Vet MSP Database}

This evaluation was done in 2 steps. First, we tested a collection of previously identified microorganisms $(\mathrm{n}=$ 30) originally used in the national mastitis proficiency test (Table 1) using the BDAL database (Bruker Daltonics) and the local DTU-Vet MSP database (National Veterinary Institute, Lyngby, Denmark) (Supplemental Table S1; https://doi.org/10.3168/jds.2018-15424). A total of 123 custom main spectra covering 15 genera were created according to Cameron et al. (2017) and Nonnemann et al. (2013). Most of the isolates used to create the main spectra belonged to the Diagnostic Unit at the Danish Technical University Veterinary Institute, Frederiksberg, Copenhagen (now Diagnostic unit at the Danish Technical University, Lyngby). Culturing was done as described above and MALDI-TOF identification, using either the direct smear or the extraction protocol, was done as described by Bizzini et al. (2010). Lack of identification of these isolates by the Biotyper software led to identification by $16 \mathrm{~S}$ rDNA sequencing and finally addition to the DTU-Vet MSP Database as reference spectra for this study.

\section{Upgrade of DTU-Vet MSP Database}

Before acquisition of spectra and inclusion of reference spectra, the instrument was calibrated with the BTS, achieving a log score of 2.2. Acquisition of each 
isolate was performed in 8 spots on the target plate, which were run in triplicate resulting in 24 spectra using the flexControl 3.4 (Bruker Daltronics). All spectra files were submitted to flexAnalysis 3.4 and Biotyper OC 3.1 (Bruker Daltonics). Spectra were smoothed and baseline subtracted before assessment. If the internal control displayed a $\log$ score $<2.2$, all raw spectra from the particular run were discarded.

Low-intensity and outlier spectra were identified and manually discarded until a minimum of 20 individual spectra could be used for custom main spectra creation. In cases where intensities or frequencies did not meet the minimum standard of 20 spectra, the ethanol:formic acid:acetonitrile method and spectrum acquisition were reviewed and repeated.

\section{RESULTS}

The isolates from veterinary practice (CM or SCM, $\mathrm{n}=413)$ displayed a variety of different bacteria: 19.1\% (79/413) Staph. aureus, 23.7\% (98/413) streptococci, $15.6 \%$ (64/413) E. coli, $15.6 \%$ (64/413) non-aureus staphylococci, $3.4 \%$ (14/413) Klebsiella spp., $2.9 \%$ (12/413) Corynebacterium spp., and $2.4 \%$ (10/413) Bacillus spp., of which $1.5 \%$ (6/413) were Bacillus licheniformis; other bacteria constituted approximately $17 \%$ of the isolates. Among the bovine isolates, the Streptococcus group, consisting of nearly $24 \%$ of the isolates from veterinary practices, $12.1 \%(50 / 413)$ were Strep. uberis and $7.5 \%(31 / 413)$ were Strep. dysgalactiae. The isolates from SCM samples obtained from the research project on Staph. aureus and Strep. agalactiae $(\mathrm{n}=87)$ revealed 52\% (45/87) Staph. aureus, 39\% (34/87) Strep. agalactiae, and 9\% (8/87) Staph. haemolyticus.

In our study, $93.5 \%(386 / 413)$ of the isolates from veterinary practitioners presented a log score $>2.00$ and were identified to the species level. The remaining $6.5 \%$ were identified only to the genus level (log score 1.7-2.0), of which $2.4 \%(10 / 413)$ were assigned only as genus in the database with a log score less than 2.0. All isolates from the Staph. aureus and Strep. agalactiae project $(\mathrm{n}=87)$ were identified to the species level. A fraction of the isolates from the national mastitis proficiency test collection (Table $1 ; \mathrm{n}=3$ ) were not identified by MALDI-TOF MS, either due to lack of reference spectra or because the isolate, calculated by the Biotyper algorithm, displayed too large of a distance from the reference spectra in the database (log score $<2.0$ ). The Biotyper algorithm compares the 10 closest reference spectra and calculates the log score (distance) between the sample spectrum and the reference spectrum. Fifteen percent $(8 / 53)$ of "Staph. aureus" isolates from SCM samples $(\mathrm{n}=87)$ identified correctly by the MALDI TOF MS technique were previously misidentified as Staph. aureus by routine veterinary examination before being submitted to our laboratory, where they were identified as Staph. haemolyticus. Table 2 summarizes the range of identified bacteria causing bovine mastitis in this study. Three of the Staph. aureus isolates were small colony variants (SCV). In total, we identified 26.4\% (132/500) streptococci, $24.8 \%$ (124/500) Staph. aureus, $14.4 \%$ (72/500) non-aureus staphylococci, and $12.8 \%(64 / 500)$ E. coli as the main pathogenic bacteria causing bovine mastitis. To create a sufficient range of reference spectra covering the most frequently appearing bacteria causing mastitis, 3 isolates (Streptococcus canis, Strep. uberis, and Micrococcus luteus) were added (Table 1).

\section{DISCUSSION}

Table 2 summarizes the diagnosed bacteria causing bovine mastitis in this study. Staphylococcus aureus, E. coli, Strep. uberis, and Strep. dysgalactiae are considered the most important bacteria in bovine mastitis (Bradley, 2002; Cervinkova, 2013), which is supported by our findings; they were the 4 most frequently identified species in our study (Table 2). Minor contributors, supported by Gonçalves et al. (2014), were Corynebacterium spp., a group known for its heterogeneity and inconclusive species discrimination by classical methods (Watts et al., 2000).

One crucial requirement for MALDI-TOF is the use of pure culture specimens. It is not yet possible to identify polymicrobial samples. Suspected polymicrobial samples must be streaked and bacteria isolated and grown as pure cultures. Another is the applicability of the database for the bacteria causing mastitis. Currently, 16 non-aureus staphylococcal species along with 3 coagulase-positive staphylococcal species have been isolated from CM or SCM (Capurro et al., 2009). Tomazi et al. (2014) and Elbehiry et al. (2016) demonstrated that MALDI-TOF is a reliable technique for identifying non-aureus staphylococci specifically known to cause IMI, although Mahmmod et al. (2018) and Banach et al. (2016) argued that, currently, the BDAL database from Bruker Daltonics is not sufficient to establish identification of non-aureus staphylococci associated with bovine mastitis. In particular, the bacteria that colonize the teat apex were challenging to identify using MALDI-TOF MS due to limited coverage of the database entries. However, in Mahmmod et al. (2018), several isolates were identified by $16 \mathrm{~S}$ rDNA sequencing and the spectra used to amend the database with additional non-aureus staphylococcus species (Mahmmod et al., 2018). In the present study, we identified 14 Staphylococcus species and only a few of the isolates had scores below that required to identify at the species level. We 
therefore conclude that MALDI-TOF MS with the amended database is very reliable for identification of staphylococci. Savage et al. (2017) also concluded that MALDI-TOF MS was superior in both accuracy and cost efficacy for identification of gram-positive cocci. Cost efficacy includes both consumables and labor costs. A study by Schabauer et al. (2014) confirmed that MALDI-TOF MS was suitable for differentiation of Streptococcus species associated with bovine mastitis. We identified 5 Streptococcus species to the species level. Gram-positive bacteria tend to be slightly more difficult to identify to the species level by the direct smear method but when isolates are subjected to the ethanol:formic acid:acetonitrile method, identification can be increased by more than $10 \%$ (Schulthess et al., 2013). An overall rate of more than $75 \%$ species identification using direct smear application (Bizzini et al., 2010; McElvania-TeKippe et al., 2013) is supported by the findings of the current study (93.5\%). It is noteworthy that application of $70 \%$ formic acid as a layer on top of the colony material before applying matrix can increase the identification rate (McElvania-TeKippe et al., 2013; Ge et al., 2017). When a yeast infection is suspected, the direct smear approach is not sufficient, as described by Cassagne et al. (2013); it requires the ethanol:formic acid:nitrile protocol. Furthermore, the ethanol:formic acid:nitrile protocol is necessary for species identification of Bacillus spp. and Acinetobacter spp., although the direct smear approach can be used on colonies of Bacillus licheniformis $<18 \mathrm{~h}$, whereas more mature colonies require the former protocol (our unpublished results).

In the present study, MALDI-TOF MS was an efficient technique for identification of streptococci, staphylococci, and Enterobacteriaceae, although species identification was less certain in some genera. For example, 4 of 6 Acinetobacter, 2 of 9 Corynebacterium, and 2 of 11 Bacillus were identified only to the genus level (Table $2)$. This is in accordance with observations of Savage et al. (2017) and suggests an improvement of databases for those genera. For several years, $16 \mathrm{~S}$ rDNA sequencing has been superior to other automated identification systems for microbial identification, even phenotypical identification, although like the MS technique, the success of $16 \mathrm{~S}$ rDNA sequencing relies on a well-developed database (Bizzini et al., 2010; Schröttner et al., 2014). Even though the MS database from Bruker Daltonics consists of more than 7,000 reference spectra, there seems to be a difference in the spectra depending on the source of isolates (e.g., intermammary glands vs. teat apex; Mahmmod et al., 2018). Since there is a difference in spectra depending on the source, there is a constant demand for evolving and applying the MALDI-TOF MS technique in new diagnostic subar- eas within microbial identification, such as mastitis pathogens, fish pathogens, or environmental microbial isolates (Timperio et al., 2017), an ongoing expansion of such databases is required. Isolates attaining log scores between 1.7 and 2.0 (i.e., identification only to the genus level) indicate that the current database is inadequate for species identification and requires either other identification methods or an addition of reference spectra in the database. The BDAL database and Biotyper software from Bruker Daltonics is a frequently used setup for identification of bacterial and fungi pathogens, although it is not the only system used. The VITEK MS system from bioMérieux (Marcy l'Étoile, France) is a valid platform used for both human and animal pathogens (Kärpänoja et al., 2014; Deak et al., 2015; Marín et al., 2017), although different databases are used in the MS assays developed by Bruker Daltonics and bioMérieux. Well-developed databases are of utmost importance for optimal performance of the MALDI-TOF MS technique.

Historically, bovine mastitis has been treated onsite based on clinical observations, rather than on identification and susceptibility of the pathogen. Antimicrobial intervention at an early stage is a precautionary measure against the risk of losing function of one or more quarters and to prevent lower yield during the rest of the lactation period (Espetvedt et al., 2013). However, bacterial culture carried out in veterinary laboratories or on farm may not achieve high accuracy in species identification. Accurate species identification enables targeted use of antibiotics and speciesspecific mastitis control plans. Rapid identification of the pathogen will, to some extent, limit the use of broad-spectrum antibiotics based on prior experience and knowledge about the bacteria without the need for susceptibility tests, and contribute to the reduction in use of broad-spectrum antibiotics. There is a push to use narrow-spectrum antibiotics, to reduce the use of antibiotics that are critical for humans, and, preferably, to treat after only laboratory diagnosis and susceptibility testing (Anonymous, 2013). In that respect, 8 of the Staph. haemolyticus isolates in this study had first been misidentified by routine examination (i.e., by hemolysis of the blood agar plate) as Staph. aureus. Later, these isolates were verified by routine standards in our laboratory. Previously, Staph. haemolyticus was not regarded a major bovine mastitis pathogen, but this CNS has now evolved to be an important pathogen (Pyörälä and Taponen, 2009; Fessler et al., 2010). Therefore, such misinterpretations can lead to improper treatment and overuse of antibiotics or an erroneous prognosis for the cow. The SCV phenotype is frequently seen in Staph. aureus, causing the bacteria to be misidentified by classical methods. The SCV are slow-growing, whit- 
ish, pinpoint colonies $(>10$-fold smaller than regular Staph. aureus) and express a delayed coagulase reaction, lesser hemolysis, and decreased sensitivity toward aminoglycosides and bacterial toxins (Youmans et al., 1937; von Eiff et al., 1997; Biswas et al., 2009). By their appearance on blood agar, the colonies can easily be misidentified as hemolytic streptococci, which could lead to the wrong choice of treatment. Staphylococcus aureus SCV have often been associated with chronic or recurrent infections, and the SCV state allows the bacterium to be better adapted to intracellular survival (von Eiff et al., 2000). It is noteworthy that MALDI TOF MS was still able to identify SCV correctly. At present, Denmark does not surveille critical bovine mastitis bacteria or the development of antibiotic resistance. The antibiotic resistance scheme in Denmark is evolving (DANMAP, 2014, 2017), but not up to date for bovine mastitis. Such investigations would contribute to greater knowledge to the literature, but are beyond the scope of the present study. Attempts to type bacteria using MALDI TOF MS or predict antimicrobial resistance have been somewhat successful but still need considerable development. Elbehiry et al. (2016) detected higher intensities of 3 specific biomarker peaks (3.993, 4.121, and 5.845 Da) in methicillin-resistant Staph. aureus (MRSA) isolates causing bovine mastitis. These particular peaks were not seen in methicillin-sensitive Staph. aureus (MSSA) isolates. However, insufficient ability to type Staph. aureus and Enterococcus faecium was demonstrated using MALDI-TOF MS by Lasch et al. (2014). Whether or not these conflicting results rely on different pre-analytical conditions, uniform guidelines could improve the performance of MALDI-TOF MS-based typing methods considerably, as suggested by Sauget et al. (2017).

To use the MALDI-TOF MS method for rapid diagnosis of bovine mastitis bacteria, agar plates or secreta sent to the laboratory preferably on agar plates or as a milk sample, respectively. Veterinarians can draw a milk sample, plate it on an agar plate, and send the plate by mail to the laboratory, and the diagnosis is often ready on the day of arrival at the laboratory. If subculture is required, the diagnosis will be available 18 to $22 \mathrm{~h}$ later. Although promising, this method of diagnosis has its shortcomings, primarily in the prediagnostic phase. Bovine mastitis samples are drawn from live animals and the risk of contamination with environmental microorganisms exists. Additionally, the possibility of contamination and overgrowth with Proteus spp. exists, mainly during summer or when a sample is in transit to the laboratory for several days. In the diagnostic phase, selection of the suspected pathogen for identification; for example, from plates carrying several bacterial species, still relies upon qualified personnel.

\section{CONCLUSIONS}

We amended a commercial MALDI-TOF MS database to accommodate additional species for identification of udder pathogens. We demonstrated the applicability of MALDI-TOF MS technology for mastitis diagnostics, and found it rapid and cost efficient in terms of materials and labor costs. With MALDI-TOF applied to 500 isolates, 24 genera and 61 different species were identified.

\section{ACKNOWLEDGMENTS}

This study was supported by a grant from the Danish Veterinary and Food Administration and from the Danish Milk Levy Fund for the STOPMAST project (Denmark). We are very grateful to the veterinarians who kindly provided the samples and to Sophia Rasmussen, Susanne Ranebro, and Margrethe Carlsen (Technical University of Denmark, National Veterinary Institute, Lyngby) for technical laboratory assistance. BN carried out the MALDI-TOF MS analysis and interpretation of results, participated in analysis of all results in this manuscript and drafting and writing the manuscript; UL was involved in drafting and critically revising contents of the manuscript; KAK participated in acquisition, analysis, and interpretation of $16 \mathrm{~S}$ rDNA sequencing results; LS and ICK contributed with milk samples from an ongoing project as well as critical revising of the manuscript; KP was involved in communicating with veterinarian clinics, providing samples and isolates, drafting and designing the manuscript, as well as critically revising the manuscript and giving final approval of the version to be published. All authors have read and approved the final manuscript. All authors declare that they have no competing interests.

\section{REFERENCES}

Anonymous. 2013. Retningslinjer for brug af antibiotika til kvæe i Danmark. Videnscenteret Landbrug, Kvæg; Den Danske Dyrlægeforening, KU Sund; Århus Universiteit. https://herd.ku.dk/ documents/Brug_af_Antibiotika_i_Kvaeg_final_2013_09_05.pdf.

Bader, O., M. Weig, L. Taverne-Ghadwal, R. Lugert, U. Gross, and M. Kuhns. 2011. Improved clinical laboratory identification of human pathogenic yeasts by matrix-assisted laser desorption ionization time-of-flight mass spectrometry. Clin. Microbiol. Infect. 17:1359 1365. https://doi.org/10.1111/j.1469-0691.2010.03398.x.

Banach, T., M. Bochniarz, P. Łyp, Ł. Adaszek, W. Wawron, B. Furmaga, M. Skrzypczak, J. Ziętek, and S. Winiarczyk. 2016. Application of matrix-assisted laser desorption ionization time-of-flight mass spectrometry for identification of coagulase-negative staphylococci isolated from milk of cows with subclinical mastitis. Pol. J. Vet. Sci. 19:627-632. https://doi.org/10.1515/pjvs-2016-0078. 
Barkema, H. W., Y. H. Schukken, T. J. Lam, M. L. Beiboer, H. Wilmink, G. Benedictus, and A. Brand. 1998. Incidence of clinical mastitis in dairy herds grouped in three categories by bulk milk somatic cell counts. J. Dairy Sci. 81:411-419. https://doi.org/10 .3168/jds.S0022-0302(98)75591-2.

Barreiro, J. R., C. R. Ferreira, G. B. Sanvido, M. Kostrzewa, T. Maier, B. Wegemann, V. Böttcher, M. N. Eberlin, and M. V. dos Santos. 2010. Short communication: Identification of subclinical cow mastitis pathogens in milk by matrix-assisted laser desorption/ionization time-of-flight mass spectrometry. J. Dairy Sci. 93:5661-5667. https://doi.org/10.3168/jds.2010-3614.

Benagli, C., V. Rossi, M. Dolina, M. Tonolla, and O. Petrini. 2011. Matrix-assisted laser desorption ionization-time of flight mass spectrometry for the identification of clinically relevant bacteria. PLoS One 6. https://doi.org/10.1371/journal.pone.0016424.

Bes, M., V. Guerin-Faublee, H. Meugnier, J. Etienne, and J. Freney. 2000. Improvement of the identification of staphylococci isolated from bovine mammary infections using molecular methods. Vet. Microbiol. 71:287-294.

Bi, Y., Y. J. Wang, Y. Qin, R. Guix Vallverdu, J. Maldonado Garcia, W. Sun, S. Li, and Z. Cao. 2016. Prevalence of bovine mastitis pathogens in bulk tank milk in China. PLoS One 11:e0155621. https://doi.org/10.1371/journal.pone.0155621.

Biswas, L., R. Biswas, M. Schlag, R. Bertram, and F. Götz. 2009. Small-colony variant selection as a survival strategy for Staphylococcus aureus in the presence of Pseudomonas aeruginosa. Appl. Environ. Microbiol. 75:6910-6912. https://doi.org/10.1128/AEM .01211-09.

Bizzini, A., C. Durussel, J. Bille, G. Greub, and G. Prod'hom. 2010. Performance of matrix-assisted laser desorption ionization-time of flight mass spectrometry for identification of bacterial strains routinely isolated in a clinical microbiology laboratory. J. Clin. Microbiol. 48:1549-1554. https://doi.org/10.1128/JCM.01794-09.

Botrel, M. A., M. Haenni, E. Morignat, P. Sulpice, J. Y. Madec, and D. Calavas. 2010. Distribution and antimicrobial resistance of clinical and subclinical mastitis pathogens in dairy cows in RhoneAlpes, France. Foodborne Pathog. Dis. 7:479-487. https://doi.org/ $10.1089 /$ fpd.2009.0425.

Bradley, A. J. 2002. Bovine mastitis: An evolving disease. Vet. J. 164:116-128. https://doi.org/10.1053/tvjl.2002.0724.

Cameron, M., H. W. Barkema, J. De Buck, S. De Vliegher, M. Chaffer, J. Lewis, and G. P. Keefe. 2017. Identification of bovine-associated coagulase-negative staphylococci by matrix-assisted laser desorption/ionization time-of-flight mass spectrometry using a direct transfer protocol. J. Dairy Sci. 100:2137-2147. https://doi.org/10 $.3168 /$ jds.2016-12020.

Capurro, A., K. Artursson, K. P. Waller, B. Bengtsson, H. EricssonUnnerstad, and A. Aspán. 2009. Comparison of a commercialized phenotyping system, antimicrobial susceptibility testing, and tuf gene sequence-based genotyping for species-level identification of coagulase-negative staphylococci isolated from cases of bovine mastitis. Vet. Microbiol. 134:327-333. https://doi.org/10.1016/j .vetmic.2008.08.028.

Cassagne, C., A. L. Cella, P. Suchon, A. C. Normand, S. Ranque, and R. Piarroux. 2013. Evaluation of four pretreatment procedures for MALDI-TOF MS yeast identification in the routine clinical laboratory. Med. Mycol. 51:371-377. https://doi.org/10.3109/ 13693786.2012.720720.

Cervinkova, D. 2013. Prevalence of mastitis pathogens in milk from clinically healthy cows. Vet. Med. (Praha) 58:567-575.

Cherkaoui, A., J. Hibbs, S. Emonet, M. Tangomo, M. Girard, P. Francois, and J. Schrenzel. 2010. Comparison of two matrix-assisted laser desorption ionization-time of flight mass spectrometry methods with conventional phenotypic identification for routine identification of bacteria to the species level. J. Clin. Microbiol. 48:11691175. https://doi.org/10.1128/JCM.01881-09.

DANMAP. 2014. DANMAP 2013: Use of antimicrobial agents and occurrence of antimicrobial resistance in bacteria form food animals, food and humans in Denmark. Accessed Dec. 24, 2018. http:// orbit.dtu.dk/files/140535625/DANMAP_2016_LOW_241017.pdf.
DANMAP. 2017. DANMAP 2016: Use of antimicrobial agents and occurrence of antimicrobial resistance in bacteria from food animals, food and humans in Denmark. Accessed Dec. 24, 2018. http:// orbit.dtu.dk/files/140535625/DANMAP_2016_LOW_241017.pdf.

Deak, E., C. L. Charlton, A. M. Bobenchik, S. A. Miller, S. Pollett, I. H. McHardy, M. T. Wu, and O. B. Garner. 2015. Comparison of the VITEK MS and Bruker Microflex LT MALDI-TOF MS platforms for routine identification of commonly isolated bacteria and yeast in the clinical microbiology laboratory. Diagn. Microbiol. Infect. Dis. 81:27-33. https://doi.org/10.1016/j.diagmicrobio 2014.09.018.

Eigner, U. 2009. Performance of a matrix-assisted laser desorption ionization-time-of-flight mass spectrometry system for the identification of bacterial isolates in the clinical routine laboratory. Clin. Lab. 55:289-296.

Elbehiry, A., M. Al-Dubaib, E. Marzouk, S. Osman, and H. Edrees. 2016. Performance of MALDI Biotyper compared with VITEK ${ }^{\mathrm{TM}}$ 2 compact system for fast identification and discrimination of Staphylococcus species isolated from bovine mastitis. MicrobiologyOpen 5:1061-1070. https://doi.org/10.1002/mbo3.389.

Espetvedt, M., A.-K. Lind, C. Wolff, S. Rintakoski, A.-M. Virtala, and A. Lindberg. 2013. Nordic dairy farmers' threshold for contacting a veterinarian and consequences for disease recording: Mild clinical mastitis as an example. Prev. Vet. Med. 108:114-124. https://doi .org/10.1016/j.prevetmed.2012.07.014.

Fessler, A. T., C. Billerbeck, K. Kadlec, and S. Schwarz. 2010. Identification and characterization of methicillin-resistant coagulasenegative staphylococci from bovine mastitis. J. Antimicrob. Chemother. 65:1576-1582. https://doi.org/10.1093/jac/dkq172.

Ge, M.-C., A.-J. Kuo, K.-L. Liu, Y.-H. Wen, J.-H. Chia, P.-Y. Chang, M.-H. Lee, T.-L. Wu, S.-C. Chang, and J.-J. Lu. 2017. Routine identification of microorganisms by matrix-assisted laser desorption ionization time-of-flight mass spectrometry: Success rate, economic analysis, and clinical outcome. J. Microbiol. Immunol. Infect. 50:662-668. https://doi.org/10.1016/j.jmii.2016.06.002.

Gianneechini, R., C. Concha, R. Rivero, I. Delucci, and J. Moreno López. 2002. Occurrence of clinical and sub-clinical mastitis in dairy herds in the west littoral region in Uruguay. Acta Vet. Scand. 43:221-230. https://doi.org/10.1186/1751-0147-43-221.

Gonçalves, J. L., T. Tomazi, J. R. Barreiro, P. A. Braga, C. R. Ferreira, J. P. Araújo Junior, M. N. Eberlin, and M. V. dos Santos. 2014. Identification of Corynebacterium spp. isolated from bovine intramammary infections by matrix-assisted laser desorption ionization-time of flight mass spectrometry. Vet. Microbiol. 173:147151. https://doi.org/10.1016/j.vetmic.2014.06.028.

Hand, K. J., A. Godkin, and D. F. Kelton. 2012. Milk production and somatic cell counts: A cow-level analysis. J. Dairy Sci. 95:1358 1362. https://doi.org/10.3168/jds.2011-4927.

Hsieh, S.-Y., C.-L. Tseng, Y.-S. Lee, A.-J. Kuo, C.-F. Sun, Y.-H. Lin, and J.-K. Chen. 2008. Highly efficient classification and identification of human pathogenic bacteria by MALDI-TOF MS. Mol. Cell. Proteomics 7:448-456. https://doi.org/10.1074/mcp.M700339 -MCP200.

Kärpänoja, P., I. Harju, K. Rantakokko-Jalava, M. Haanperä, and H. Sarkkinen. 2014. Evaluation of two matrix-assisted laser desorption ionization-time of flight mass spectrometry systems for identification of viridans group streptococci. Eur. J. Clin. Microbiol. Infect. Dis. 33:779-788. https://doi.org/10.1007/s10096-013-2012-8.

Lasch, P., C. Fleige, M. Stämmler, F. Layer, U. Nübel, W. Witte, and G. Werner. 2014. Insufficient discriminatory power of MALDITOF mass spectrometry for typing of Enterococcus faecium and Staphylococcus aureus isolates. J. Microbiol. Methods 100:58-69. https://doi.org/10.1016/j.mimet.2014.02.015.

Leitner, G. 2012. Options for handling chronic subclinical mastitis during lactation in modern dairy farms. Isr. J. Vet. Med. 67:162-169.

Mahmmod, Y. S., L. Svennesen, K. Pedersen, B. Nonnemann, and I. Klaas. 2018. Typability of MALDI-TOF assay for identification of coagulase-negative staphylococci associated with bovine intramammary infections and teat apex colonization. J. Dairy Sci. 101:9430-9438. https://doi.org/10.3168/ jds.2018-14579. 
Marín, M., R. Arroyo, I. Espinosa-Martos, L. Fernández, and J. M. Rodríguez. 2017. Identification of emerging human mastitis pathogens by MALDI-TOF and assessment of their antibiotic resistance patterns. Front. Microbiol. 8:1258. https://doi.org/10.3389/fmicb .2017.01258.

McElvania-TeKippe, E., S. Shuey, D. W. Winkler, M. A. Butler, and C. A. D. Burnham. 2013. Optimizing identification of clinically relevant gram-positive organisms by use of the Bruker Biotyper matrix-assisted laser desorption ionization-time of flight mass spectrometry system. J. Clin. Microbiol. 51:1421-1427. https:// doi.org/10.1128/JCM.02680-12.

Nonnemann, B., M. Tvede, and T. Bjarnsholt. 2013. Identification of pathogenic microorganisms directly from positive blood vials by matrix-assisted laser desorption/ionization time of flight mass spectrometry. APMIS 121:871-877.

Pyörälä, S., and S. Taponen. 2009. Coagulase-negative staphylococciEmerging mastitis pathogens. Vet. Microbiol. 134:3-8. https://doi .org/10.1016/j.vetmic.2008.09.015.

Randall, L. P., F. Lemma, M. Koylass, J. Rogers, R. D. Ayling, D. Worth, M. Klita, A. Steventon, K. Line, P. Wragg, J. Muchowski, M. Kostrzewa, and A. M. Whatmore. 2015. Evaluation of MALDITOF as a method for the identification of bacteria in the veterinary diagnostic laboratory. Res. Vet. Sci. 101:42-49. https://doi .org/10.1016/j.rvsc.2015.05.018.

Rodrigues, N. M., G. F. Bronzato, G. S. Santiago, L. A. Botelho, B. M. Moreira, I. D. Coelho, M. M. de Souza, and S. M. Coelho. 2017. The matrix-assisted laser desorption ionization-time of flight mass spectrometry (MALDI-TOF MS) identification versus biochemical tests: A study with enterobacteria from a dairy cattle environment. Braz. J. Microbiol. 48:132-138. https://doi.org/10.1016/j .bjm.2016.07.025.

Sauget, M., B. Valot, X. Bertrand, and D. Hocquet. 2017. Can MALDI-TOF mass spectrometry reasonably type bacteria. Trends Microbiol. 25:447-455. https://doi.org/10.1016/j.tim.2016.12.006.

Savage, E., S. Chothe, V. Lintner, T. Pierre, S. Kariyawasam, T. Matthews, S. Miller, D. Tewari, and B. Jayarao. 2017. Evaluation of three bacterial identification systems for species identification of bacteria isolated from bovine mastitis and bulk tank milk samples. Foodborne Pathog. Dis. 14:177-187. https://doi.org/10.1089/fdp .2016 .2222

Schabauer, L., M. Wenning, I. Huber, and M. Ehling-Schulz. 2014. Novel physico-chemical diagnostic tools for high throughput identification of bovine mastitis associated gram-positive, catalasenegative cocci. BMC Vet. Res. 10:156. https://doi.org/10.1186/ 1746-6148-10-156.

Schröttner, P., W. W. Rudolph, B. R. Eing, S. Bertram, and F. Gunzer. 2014. Comparison of VITEK2, MALDI-TOF MS, and 16S rDNA sequencing for identification of Myroides odoratus and Myroides odoratimimus. Diagn. Microbiol. Infect. Dis. 79:155-159. https://doi.org/10.1016/j.diagmicrobio.2014.02.002.

Schulthess, B., K. Brodner, G. V. Bloemberg, R. Zbinden, E. C. Böttger, and M. Hombach. 2013. Identification of gram-positive cocci by use of matrix-assisted laser desorption ionization-time of flight mass spectrometry: Comparison of different preparation methods and implementation of a practical algorithm for routine diagnostics. J. Clin. Microbiol. 51:1834-1840. https://doi.org/10.1128/ JCM.02654-12.

Seng, P., M. Drancourt, F. Gouriet, B. La Scola, P. E. Fournier, J. M Rolain, and D. Raoult. 2009. Ongoing revolution in bacteriology: Routine identification of bacteria by matrix-assisted laser desorption ionization time-of-flight mass spectrometry. Clin. Infect. Dis. 49:543-551. https://doi.org/10.1086/600885.

Strube, M. L., J. E. Hansen, S. Rasmussen, and K. Pedersen. 2018. A high resolution investigation of the Staphylococcus genus in the MRSA-associated microbiota using Tuf specific primers. Sci. Rep. 8:12751. https://doi.org/10.1038/s41598-018-30689-y.
Suh, M.-J., D.-M. Hamburg, S. T. Gregory, A. E. Dahlberg, and P. A. Limbach. 2005. Extending ribosomal protein identifications to unsequenced bacterial strains using matrix-assisted laser desorption/ionization mass spectrometry. Proteomics 5:4818-4831. https: //doi.org/10.1002/pmic.200402111.

Taponen, S., H. Simojoki, M. Haveri, H. D. Larsen, and S. Pyörälä 2006. Clinical characteristics and persistence of bovine mastitis caused by different species of coagulase-negative staphylococci identified with API or AFLP. Vet. Microbiol. 115:199-207. https:/ /doi.org/10.1016/j.vetmic.2006.02.001.

Tenhagen, B.-A., G. Köster, J. Wallmann, and W. Heuwieser. 2006. Prevalence of mastitis pathogens and their resistance against antimicrobial agents in dairy cows in Brandenburg, Germany. J. Dairy Sci. 89:2542-2551. https://doi.org/10.3168/jds.S0022 -0302(06)72330-X.

Timperio, A. M., S. Gorrasi, L. Zolla, and M. Fenice. 2017. Evaluation of MALDI-TOF mass spectrometry and MALDI biotyper in comparison to 16S rDNA sequencing for the identification of bacteria isolated from Arctic sea water. PLoS One 12:e0181860. https://doi .org/10.1371/journal.pone.0181860.

Todhunter, D. A., K. L. Smith, J. S. Hogan, and P. S. Schoenberger. 1991. Gram-negative bacterial infections of the mammary gland in cows. Am. J. Vet. Res. 52:184-188.

Tomazi, T., J. L. Gonçalves, J. R. Barreiro, P. A. De Campos Braga, L. F. Prada, E. Silva, M. N. Eberlin, and M. V. Dos Santos. 2014. Identification of coagulase-negative staphylococci from bovine intramammary infection by matrix-assisted laser desorption ionization-time of flight mass spectrometry. J. Clin. Microbiol. 52:1658-1663. https://doi.org/10.1128/JCM.03032-13.

Valde, J. P. 2004. Cumulative risk of bovine mastitis treatments in Denmark, Finland, Norway and Sweden. Acta Vet. Scand. 45:201210.

van Veen, S. Q., E. C. J. Claas, and E. J. Kuijper. 2010. High-throughput identification of bacteria and yeast by matrix-assisted laser desorption ionization-time of flight mass spectrometry in conventional medical microbiology laboratories. J. Clin. Microbiol. 48:900-907. https://doi.org/10.1128/JCM.02071-09.

Vanderhaeghen, W., T. Cerpentier, C. Adriaensen, J. Vicca, K. Hermans, and P. Butaye. 2010. Methicillin-resistant Staphylococcus aureus (MRSA) ST398 associated with clinical and subclinical mastitis in Belgian cows. Vet. Microbiol. 144:166-171. https://doi .org/10.1016/j.vetmic.2009.12.044.

von Eiff, C., C. Heilmann, R. A. Proctor, C. Woltz, G. Peters, and F. Götz. 1997. A site-directed Staphylococcus aureus hemB mutant is a small-colony variant which persists intracellularly. J. Bacteriol. 179:4706-4712. https://doi.org/10.1128/jb.179.15.4706-4712.1997.

von Eiff, C., R. A. Proctor, and G. Peters. 2000. Staphylococcus aureus small colony variants: Formation and clinical impact. Int. J. Clin. Pract. Suppl. 115:44-49.

Watts, J. L., D. E. Lowery, J. F. Teel, and S. Rossbach. 2000. Identification of Corynebacterium bovis and other coryneforms isolated from bovine mammary glands. J. Dairy Sci. 83:2373-2379. https:/ /doi.org/10.3168/jds.S0022-0302(00)75126-5.

Werner, G., C. Fleige, A. T. Feßler, M. Timke, M. Kostrzewa, M. Zischka, T. Peters, H. Kaspar, and S. Schwarz. 2012. Improved identification including MALDI-TOF mass spectrometry analysis of group D streptococci from bovine mastitis and subsequent molecular characterization of corresponding Enterococcus faecalis and Enterococcus faecium isolates. Vet. Microbiol. 160:162-169. https:/ /doi.org/10.1016/j.vetmic.2012.05.019.

Youmans, G. P., E. H. Williston, and M. Simon. 1937. Production of small colony variants of Staphylococcus aureus. Proc. Soc. Exp. Biol. Med. 36:94-96. 